\title{
Welkam Toktok
}

\author{
Jif Kalkot Murmur
}

Daerekta blong miusiem, ol jeaman mo presiden blong ol man filwoka, woman filwoka, riseja from defren kantri long yumi long Pasifik mo long Europe, olgeta we oli save stap long ples ia, ol obsevas, ol midias, ol jifs, fren we hemi stap long ples ia. Mi mi tekem tis taem, mi tekem hona ia, blong save welkamem yufala evriwan bak long aelan blong yumi long Efate, ples we sam long yufala i bin stap bifo mo kontiniu blong stap kam, mo yufala i laekem tumas!

Mi wantem mekem wan smol toktok olsem se, olsem mi neva save se bae mi kam wan jif. Mi bin bon olsem pikinini mi wan twin, twin pikinini wetem brata blong mi. Mi skul afta save blong mi long skul i karem mi go go mi kam wan skul tija we mi tij blong plante plante yia. Mi kam wan Presbyterian elda we mi prijim tabu tok blong God long jos fo plante ples truaot ol aelan long Vanuatu go go long 1993 olsem bifo 1983 i kam 1993 i kam toktok i stap kam long mi nao se: 'Yu mas kam wan jif'. Be mi harem se jif hemi no wan samting blong mi nating. Mi neva bin tren blong kam wan jif. Mi no gat save long wan samting abaot jif. Mi save nomo blong mi, mi tij long klasrum, stanap long blakbod toktok long Inglis long pikinini nomo evridei. Hemia nao hemi wok blong mi. Taem mi mi stap long skul mi stap talem long ol pikinini, mi panisim olgeta se, 'Don't speak in language speak in English', sam taem mi panisim olgeta, yu raetem handred taems long pepa blong yu se: 'I must talk in English, I must speak in English.' Hemia nao wok blong mi bifo.

Be i hapen se taem we long 1990 hem i kam go go i kam naoia hat blong mi, i stap filim o mi stap harem save se yes ating i mo gud mi mi go jif mekem se $1993 \mathrm{mi}$ kam wan jif nao. Taem mi kam jif nao mi harem se mi mekem wan bigfala trabol i stap finis, bigfala trabol blong mi i stap we mi mi tijim narafala kalja long ol pikinini blong mi stret. Oli nomo save toktok long lanwis blong mi, i nomo save sing long lanwis blong mi, i nomo save tanis long kastom tanis blong mi we mi mi sapos blong mekem fastaem be mi mekem nara samting i stap fastaem blong mi winim hemia no gat nao vilej blong mi long Mangaliliu taem we mi mi stap toktok, pikinini i toktok i kam: 'He yu no toktok spos yu toktok long Bislama yu no stap long yad blong mi yu aot long yad blong mi, yu go long yad blong yu.' Rao rao blong mi naoia i stap olsem nao.

Be mi mi praod ia mi wan praod jif naoia mi flas gud ia naoia mi mi stanap ia, mi stap talem from se taem we Jean Guiart long 1950 we hemi kam blong mekem risej long ol smol smol storian blong yumi, Jean Guiart hemi wan prapa stamba man nao i mekem ol samting ia se oli stap in ples taem we José Garanger i kam 
papa blong mi nao i talem yes long José Garanger olsem se bambae risej i tekem ples. Fasin blong digim kraon i go go kasem 1996 i kam ia mi mo boe blong mi Douglas mitufala i pat blong hem tu mi praod se mi tu mi stat blong talem yes taem we Matthew Spriggs wetem ol narafala oli kam blong mekem kastom long mi wetem Ralph, Daerekta, taem oli kam mekem kastom long mi blong mifala i statem dedikesen. Olsem mi bin talem mi tijim fastaem mi mi praod mi flas tumas ia from se mi save karem bak mo naoia taem we mi mi toktok mi no toktok nating nomo be toktok blong mi hemi paoa from se mi stap filim se mi stap go bak long stret rod. Witaot ol risej blong yufala we yufala i bin mekem mi ting se mifala olsem bebe long wan pat blong wol.

Be fastaem mebi ol bubu blong mifala oli kam, taem samfala oli kam, 'E man ia i kam blong mekem wanem bakegen ia', be naoia we mi mi stap stanap long ples ia tudei mi mi luk se kaming blong yu, yufala long taem ia we yufala stap wokbaot hemi wan gudwan, mo wan impoten wan, mo hemi wan gudfala samting blong mifala. We mi glad tu we i stap long ediukesen buk naoia we wan gel i stap naoia wetem yumi Sara we hem tu i bin mekem i stap long buk naoia ol pikinini oli ridim. Naoia mi tu samtaem mi toktok mi ron i go bak long buk blong Sara blong mi mi ridim bakegen be olsem mi no save talem plante toktok mo be yufala i bin save finis mo kontiniu blong mekem, mi samtaem mi kros, mi krae, mi kros se hu i talem long ol misinari se oli kam long Vanuatu mo mi mas ones long yufala mi resaen long elda finis long last yia. Naoia mi stap klisim jos bakegen nao, mi stap wantem se bae mi nomo go prea long Sande nao from se taem mifala i mekem wan smol donesen i kam long olgeta long New Zealand High Com se bae Sande mi mi tanis kastom nao from taem turis blong mi o i kam wan Wol Heritij blong yumi we hemi no yet, spos hemi kam in ples bae Sande i kam, bae mi mi go tanis nao bae mi mi nomo go prea. So mi jes ritaea mi jes karem eli ritaeamen blong mi long saed blong jos long last Oktoba and naoia mi karem wan hat nomo wan mat blong jif, wan mat blong kastom. Ating hemia nomo tangkiu tumas an welkam long miting ia. 


\title{
Welcome Speech
}

\author{
Chief Kalkot Murmur
}

Museum Director, Chairman and President of the man fieldworkers, woman fieldworkers, researchers from around the Pacific and from Europe, everyone who is able to attend here, observers, media, Chiefs, and friends who are here today. I would like to take this time, and take this honour, to welcome you all to our island, Efate, where some of you have been before and still visit, and seem to like rather a lot!

I want to tell you briefly that, before, I never thought I would become a chief. I was born with a twin brother. I went to school and with that learning I went on to become a teacher, and I was a teacher for many years. I became a Presbyterian elder and preached the word of God in churches all over Vanuatu from 1983 to 1993, but then a voice told me, 'You have to become a chief.' But I thought that being a chief was not for me at all. I had never trained to become a chief. I didn't have any knowledge of anything to do with chiefs. I knew about my own things, classroom teaching, standing up in front of a blackboard and talking in English to the kids everyday. That was my work. When I was running a classroom I would punish the kids, saying, 'Don't speak in language speak in English.' Sometimes I'd punish them by making them write a hundred times on paper, 'I must talk in English, I must speak in English.' That used to be my job.

So, when 1990 came around, my heart told me and I understood it would be better if I became a chief, so in 1993 I became a chief. But becoming a chief caused me some problems because I was teaching another culture to the children, they couldn't speak in my language, they couldn't sing in my language, they couldn't do the custom dances which I was supposed to be able to do for them, but I was busy doing other things. So in my village Mangaliliu when children come around I say, 'Hey don't you talk in Bislama in my yard, you get out of my yard, go to your yard.' I told them like that.

But I was proud, I was a proud chief, I was too flash, now I am here telling you that Jean Guiart recorded our stories in 1950, he did some research. Then José Garanger came, my father said yes to him and so his research went ahead. So they dug the ground until in 1996 me and my son Douglas were also able to approve the team with Matthew Spriggs and the others who made custom to me with Ralph Regenvanu, the Director of Vanuatu Kaljoral Senta, and we started the dedication. As I have said, I am very glad now because we can take back 
that knowledge, and my talk now is powerful because I have gone back on the right path. Without all the research which all of you have done we would be like babies in one part of the world.

But back then when the researchers came, maybe all our grandparents said, 'Hey, what have they come here to do?' But today, as I am here with you all I see that when you came to visit us it was good for us and it was important, and it was useful for us. I'm glad too that the research is in this textbook (Lightner and Naupa 2005) for children to read. Sometimes I also go back to this book and I read it and sometimes I'm angry. I cry. I'm angry because who told the missionaries to come to Vanuatu? I have to be honest with you. I resigned as elder last year. Now I avoid the church, I don't want to pray on Sundays, and we got a small grant from the New Zealand High Commission so that on Sundays we can do kastom dance for the tourists because my place is becoming a World Heritage area, well not yet, but if it does then we can do kastom dance. I won't be praying again. So I have retired, I took early retirement from the church last October and now I wear just one hat, the chief's mat, a kastom mat.

\section{Reference}

Lightner, Sara and Anna Naupa, 2005. Histri Blong Yumi Long Vanuatu: An Educational Resource, vols. 1-3. Port Vila: Vanuatu Cultural Centre. 